\title{
Bisiklet paylaşım istasyonlarının belirlenmesi: CBS tabanlı çok kriterli karar verme yaklaşımı
}

\author{
Elif ALKILINÇ ${ }^{1, *}$, Şehnaz CENANİ², Gülen ÇAĞDAŞ³ \\ ${ }^{1}$ Balıkesir Üniversitesi Mimarlık Fak. Mimarlık Böl., Çağış kampüsü, Balıkesir

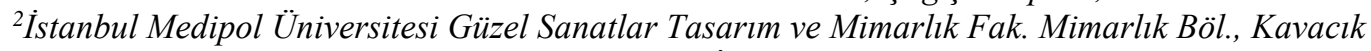 \\ yerleşkesi, İstanbul \\ ${ }^{3}$ İstanbul Teknik Üniversitesi Mimarlık Fak. Mimarlkk Böl., Taşkışla kampüsü, İstanbul
}

Gelis Tarihi (Received Date): 17.08.2020

Kabul Tarihi (Accepted Date): 13.01.2021

$\ddot{\mathbf{O z}}$

Dünya genelinde bisiklet kullanımını artırmak için bisiklet paylaşım sistemleri uygulanmaktadır. Bisiklet paylaşım istasyonlarına olan potansiyel talep ve istasyonların yerlerinin uygun şekilde seçilmesi, bu sistemlerin başarısını yüksek derecede etkilemektedir. Genç nüfusun fazla ve bisiklet kullanımı açısından mesafelerin elverişli olduğu üniversite kampüsleri çalışmanın alanını belirlemektedir. Bu çalışmada, Balıkesir Üniversitesi Çağış Kampüsünde bisiklet rotalarının ve paylaşım istasyonlarının en uygun şekilde belirlenmesi için coğrafi bilgi sistemi (CBS) tabanlı çok kriterli bir karar verme sistemi önerilmektedir. Bu kapsamda öncelikle, coğrafi bilgi sistemlerinden yararlanılarak kampüsteki bisiklet rotaları belirlenmiştir. Sonrasında ise CBS ve kullanımı oldukça yaygın çok kriterli bir karar verme yöntemi olan Analitik Hiyerarşi Süreci (AHP) birlikte kullanılarak kampüsteki öğrenci ve personelin kullanımına en uygun bisiklet paylaşım istasyonlarının belirlenmesine çalışılmıştır. Önerilen bisiklet paylaşım sistemiyle çevresel ve sosyal açılardan kampüsün daha verimli bir ortama dönüştürülmesi, öğrenci ve personele de fiziksel ve ruhsal açılardan daha sağlıklı bir ortam sunulması hedeflenmiştir. Çağış kampüsünde yapılan çalışma kapsamında, kullanılan yöntemin en uygun bisiklet paylaşım istasyonlarının yerlerinin belirlenmesi noktasında verimlilik sağladiğg ve kampüs içerisinde daha dinamik ve çevre dostu bir ulaşım imkanı oluşturduğu düşünülmektedir.

Anahtar kelimeler: Bisiklet paylaşım istasyonları, kampüs bisiklet paylaşımı, CBS, AHP.

\footnotetext{
* Elif ALKILINÇ, elif.alkilinc@ @alikesir.edu.tr, https://orcid.org/0000-0002-9260-6039

Şehnaz CENANI, sdurmazoglu@medipol.edu.tr, http://orcid.org/0000-0001-8111-586X

Gülen ÇAĞDAŞ, cagdas@itu.edu.tr, http://orcid.org/0000-0001-8853-4207
} 


\title{
Determination of bicycle sharing stations: GIS-based multi- criteria decision making approach
}

\begin{abstract}
Bicycle sharing systems are implemented to increase the use of bicycles worldwide. The potential demand for bicycle sharing stations and the appropriate selection of the locations of the stations profoundly affect the success of these systems. University campuses with a high young population and convenient distances for bicycle use, determine the sphere of the study. In this study, a geographic information system (GIS) based multi-criteria decision-making system is proposed to determine the bicycle routes and sharing stations in Balikesir University Cagis Campus in the most appropriate way. In this context, primarily, cycling routes in the campus are determined by using geographic information systems. Afterwards, GIS and Analytical Hierarchy Process (AHP), which is a widely used multi-criteria decision-making method, is used together to determine the most appropriate bike sharing stations for the use of students and staff on campus. With the recommended bike sharing system, it is aimed to transform the campus into a more efficient atmosphere in environmental and social terms, and to provide a healthier environment for students and staff in terms of physical and mental aspects. Within the scope of the study carried out on the Cagis Campus, it is thought that the method used provides efficiency in determining the locations of the most proper bike sharing stations and constitutes a more dynamic and environmentally friendly transportation opportunity within the campus.
\end{abstract}

Keywords: Bike sharing stations, campus bike sharing, GIS, AHP.

\section{Giriş}

Kentlerdeki yoğunlaşmanın sonucunda ortaya çıkan çevre ve yaşam kalitesindeki olumsuzluklarla başa çıkabilmek için, son yıllarda gelişen modern bilgi teknolojileriyle birlikte kentlerin daha akıllı ve verimli olması üzerine çalışmalar artmaktadır. Benevolo v.d. [1] çalışmalarında kentlerin hem firsat hem de hastalık mekanları olduğunu söylemektedir. Kentlerin, trafik, kirlilik ve atık üretiminin diğer yaşam alanlarından çok daha fazla olduğunu, bu nedenle hastalık ürettiklerini vurgulamaktadırlar. Kentsel alanda yaşam kalitesini artırmak için teknolojiyi kullanan "akıllı kent" kavramı ise hem çevresel kaliteyi iyileştiren hem de vatandaşlara daha iyi hizmetler sunan bir kentsel strateji olarak kabul edilmektedir. Akıllı kent kavramı, çevre, günlük yaşam, kamu güvenliği, şehir hizmetleri gibi geniş bir alanda ele alınmaktadır. Kentsel alanlarda yaşam kalitesini artırmayı hedefleyen akıllı kentlerin önemli bir boyutu da "akıllı mobilite / hareketlilik" kavramıdır [1-2]. Birçok çalışma mevcut kentlerin çoğundaki ulaşım sisteminin sürdürülemez olduğunu, hatta gelecek nesiller için bir tehdit oluşturduğunu göstermektedir [3]. Bu nedenle ortaya çıkan akıllı mobilite, kentin çevresel etkisini azaltmayı ve vatandaşlara daha iyi bir kent yaşamı sunmayı amaçlamaktadır. Akıllı mobilite, kentin en önemli özelliklerinden biri olan hareketliliğin ortaya çıkardığ 1 trafik, kirlilik, zaman ve maliyet kaybı gibi olumsuz etkileri ortadan kaldırmaya odaklandığından akıllı kentlerin en umut verici konularından biridir [1]. 
Literatürde en önemli akıllı mobilite hedefleri, kirliliğin, trafik sıkışıklığının ve gürültü kirliliğinin azaltılması, güvenlik artışı, işe (okula) gidip gelme hızının iyileştirilmesi, ulaşım maliyetlerinin düşürülmesi olarak altı kategoride toplanmıştır [1, 4]. Bu noktada, belirtilen hedeflerin hemen hepsini sağlayan bisikletin kent içi ulaşımda kullanımını artırmaya yönelik çalışmalar dünya genelinde artmaktadır. Bu noktada, Bamwesigye ve Hlavackova [3], akıllı mobilitenin bisiklet ve bu ulaşım türünün cinsiyete göre kullanımı gibi yönlerini Hollanda ve Almanya; Kenya ve Uganda ülkelerinde karşılaştırmalı olarak araştırmışlardır. Makarova v.d. [5] ise akıllı şehirlerdeki bisiklet taşımacılığını artırmaya yönelik, fiziksel gereksinimlerin azaltılarak kullanıcı sayısını artırmayı hedefleyen bir çalışma gerçekleştirmiş̧lerdir.

Yeşil, sürdürülebilir, ucuz, çevre dostu ve sağlıklı yaşam tarzını teşvik eden bisikletin akıllı mobiliteyi destekleyen bir ulaşım türü olarak tüm dünyada popülaritesi artmaktadır [5]. Bisiklet kullanımı konusundaki teşvik ve uygulamalar birçok üniversite kampüsünde de kendini göstermektedir. Çevresel, toplumsal ve bireysel ölçekte faydaları olan bisiklet kullanımı için kampüs içlerinde de bisiklet rotaları oluşturulmakta, bisiklet paylaşım sistemleri kurulmaktadır. Bisikletlere ücretsiz veya uygun fiyatlı erişim sağlanabilen bisiklet paylaşım sistemleri, kampüs içi yolculuklar için otomobil kullanımını ve böylece trafik sıkışıklığını ve gürültü / hava kirliliğini azaltmak için kullanılmaktadır. Bu sistemler yenilikçi bir ulaşım metodu olarak görülmekte, akı1lı kentlerin bir parçası haline gelmektedir [6]. En eski bisiklet paylaşım sistemi 1965 yılında Amsterdam, Hollanda'da uygulanmıştır (Beyaz bisiklet planı) [6]. O zamandan sonra da, sistemler gelişerek ve değişerek çeşitli uygulamaları sunulmuştur [7]. Bu bisiklet paylaşım sistemlerinin daha büyük bir bisiklet kullanıcısı popülasyonu yaratması, sera gazlarının azaltılması ve halk sağlığının iyileştirilmesi üzerinde derin etkileri olmuştur [8].

Balıkesir özelinde de topoğrafya ve kent içi mesafeler bisiklet için oldukça uygun olmasına rağmen, bisiklet kullanımı çok yaygın değildir. Balıkesir kent merkezindeki bu durum ile birlikte, kentten $17 \mathrm{~km}$. uzaklıkta olan Balıkesir Üniversitesi Çağış kampüsünde (Şekil 1) daha da az bisiklet kullanımı görülmektedir. Bunun başlıca nedenlerinden bazıları, kent merkezine uzaklık dolayısıyla kişisel bisikletlerle kampüse ulaşımın zor olması, kampüs içinde bisiklete bir tamirat gerektiğinde bir bakım alanının olmaması olarak sayılabilir. Balıkesir Üniversitesi Çağış Kampüsünde bisiklet paylaşım sisteminin getireceği aşağıdaki avantajlar çalışmanın ana motivasyonunu oluşturmaktadır:

- Bisikletin kampüs içi ulaşımı gibi kısa mesafeli yolculuklar için uygun olması,

- Bisiklet sürmenin seyahatten keyif alınmasına ve kullanıcıların (öğrencilerin ve personelin) fiziksel ve ruhsal sağlı̆̆ına katkıda bulunabileceğinin öngörülmesi,

- Kampüsteki otopark sorununun azalması ve böylece yoğun bir şekilde park etmiş araç görüntüsünün ve araç park yeri bulamama sorunlarının azalması, dolayısıyla binaların önünde bulunan açık alanların otopark yerine daha verimli ve sosyal bir şekilde kullanımının mümkün olması,

- Toplu etkileşimi sağlamak adına, farklı fakülteler arasında personel ve öğrenci iletişiminin artmasına katkı sağlaması,

- Ekolojik açıdan gürültü ve kirliliğin azalması, yeşil alanlara daha fazla yer verilebilmesi ve kampüsün yaşam kalitesinin artırılması ile birlikte, kampüsün daha yaşanır ve canlı hale gelmesi [9]. 
Çalışmada, Balıkesir Üniversitesi Çağış Kampüsünde, bisiklet rotaları belirlenerek, uygun bisiklet paylaşım istasyonları yerlerinin belirlenmesi amaçlanmaktadır. Böylece kurulabilecek olan bisiklet paylaşım sistemi ile birlikte kişisel bisiklete ihtiyaç olmadan, öğrenciler ve üniversite personeli kampüs içinde ulaşım aracı olarak bisiklet kullanabileceklerdir. Bisikletin kampüsteki ana ulaşım aracına dönüşmesiyle, kampüs içi ulaşımı daha elverişli ve keyifli hale getirip, daha canlı bir kampüs hayatı oluşmasına katkıda bulunması hedeflenmektedir. Bu sayede sürdürülebilir ulaşım yöntemlerinin kullanımının desteklenerek, karbon emisyon salınımının azaltılması, günümüzde akıllı kentler ile ilgili yapılan çalışmaların ana hedeflerinden olan yaşanabilirliğin (livability) ve yaşam kalitesinin (quality of life) paylaşımlı bisiklet sisteminin oluşturulması ile arttırılması da çalışmanın ana hedefleri arasındadır.

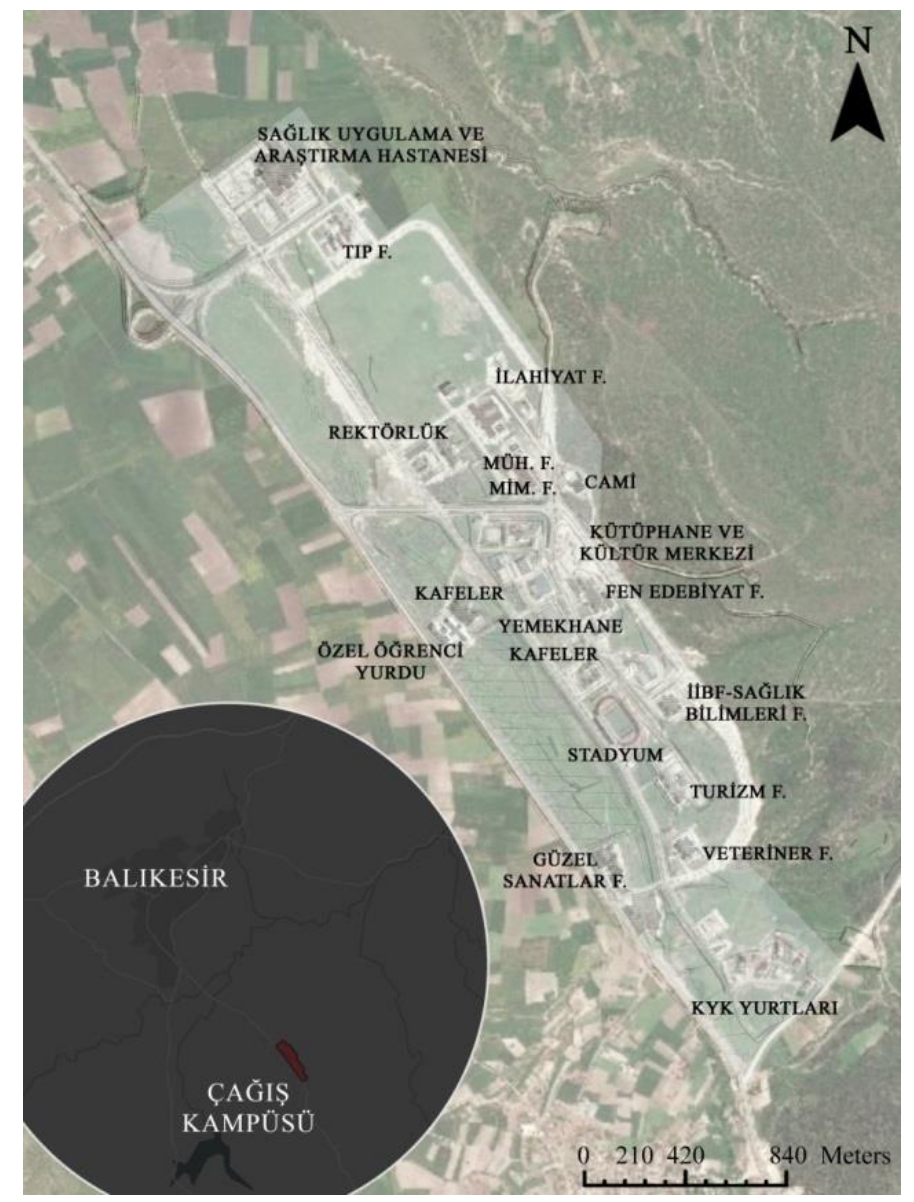

Şekil 1. Çağış Kampüsü konumu [10].

$\mathrm{Bu}$ hedef doğrultusunda, çalışma kapsamında ilk olarak muhtemel bisiklet rotaları oluşturulmuş ve farklı verilerin işlenmesini gerektiren bisiklet paylaşım istasyonları yer seçimi için, metodolojik olarak coğrafi bilgi sistemleri (CBS) ve çok kriterli karar verme yöntemleri birlikte kullanılmışlardır. Bu noktada, CBS sayısal verilerin haritalar yardımıyla görsel hale getirilmesinde yardımcı olmak için kullanılırken; çok kriterli karar verme yöntemleri ise değerlendiricilere nitel verilerin hakim olduğu karar verme işlemlerinde yardımcı olmak için 1960'lardan beri geliştirilerek kullanılmaktadır [11].

Çalışmanın izleyen bölümünde konu ile ilgili literatür araştırmasına yer verilmiş, üçüncü bölümde ise bisiklet rotaları ve paylaşım istasyonlarının belirlenmesinde kullanılacak olan yöntem ve metodolojiden bahsedilmiştir. Dördüncü bölümde, kampüs 
içinde bisiklet rotalarının ve bisiklet paylaşım istasyonları için en uygun yerlerin belirlenmesi amacıyla gerçekleştirilen analizler, değerlendirmeler ve bunlar sonrasında ulaşılan sonuçlar ele alınacak, son bölümde ise sonuçlar kısaca tartışılacaktır.

\section{Literatür incelemesi}

Bisiklet kullanımını teşvik amaçlı kurulan ve son yıllarda oldukça artan bisiklet paylaşım sistemlerinin başarısı için, belirlenen rotalar ve istasyon noktaları oldukça önem arz etmektedir ve ilgili konulardaki literatür de gittikçe genişlemektedir [6].

Bisiklet rotalarının belirlenmesi noktasında ele alınan kriterlere göre CBS'nin sıklıkla kullanıldığını görmekteyiz. Chan ve Suja [9], Singapur Ulusal Üniversitesinde uygun bisiklet yollarının tasarlanmasına yönelik CBS tabanlı çok kriterli bir karar verme yaklaşımı sunmuşlardır. Yılmaz ve Gerçek [12], İstanbul metropoliten alanında toplu taşıma sistemi ile bütünleşik bir bisiklet ağının gerçekleştirilmesi için CBS ve AHP yöntemlerini kullanan bir model önermişlerdir. Mosallanejad, Azadedel ve Dalirpour [13], Tahran'ın doğusunda yer alan bir bölgede bisiklet yollarını geliştirmek için, bazı kriterleri AHP ile değerlendirmişler ve alana ait kriter katmanlarını birleştirerek görsel hale getirmek için de CBS kullanmışlardır.

Uygun bisiklet rotalarının belirlenmesinin ardından bisiklet kullanımını teşvik eden bisiklet paylaşım sistemleri önemli hale gelmektedir. "Free-floating" veya "dock-less" sistemler [14-15] hariç, her bisiklet paylaşım sistemi, bisikletlerin kilitli olduğu belirli istasyonlara ihtiyaç duymaktadır. Bu sistemlerde yolcular, herhangi bir istasyondaki mevcut bisikletleri kiralayabilir ve park yeri olan diğer herhangi bir istasyona iade edebilirler [7]. Bisiklet paylaşım sistemlerinin başarısı için en önemli unsurlardan biri bu istasyon noktalarının uygun konumlara yerleştirilmesidir. İstasyonların erişilebilirliği ya da istasyondaki bisikletlerin kullanılabilirliği kullanıcıların memnuniyetini de etkilemekte, dolayısıyla bu sistemlerin başarısını ortaya koymaktadır [16]. İstasyon konumları, nüfusun, faaliyetlerin ve toplu taşıma ağının yakınlığ bisiklet gezileri için, uygun istasyonlar arası mesafelere sahip bir ağın yapılandırılmasına izin vermelidir [17].

Birçok çalışma, bisiklet paylaşım istasyonlarının yerlerini belirlemek için CBS tarafından sunulan mekansal analiz olanaklarından yararlanmakta ve karar noktasında çok kriterli bir karar verme yönteminden faydalanmaktadır. García-Palomares, Gutiérrez ve Latorre [17] çalışmalarında, konum belirleme modellerini kullanarak istasyonları tespit edip, istasyon kapasitesini belirlemek ve istasyonlara olan talebin özelliklerini tanımlamak için CBS tabanlı bir yöntem önermektedirler. Kabak v.d. [7], İzmir Karşıyaka'daki bisiklet paylaşım istasyonlarının mevcut durumunu değerlendirmek ve gelecekteki istasyon alanlarını mevcut istasyonlarla karşılaştırarak öneri yapmak için, birbiriyle çelişen on iki kriteri ele alarak, farklı çok kriterli karar verme yöntemlerini (AHP ve MOORA), CBS ile birleştirmiştir. Erbaş v.d. [18], çalışmalarında Ankara'da elektrikli araç şarj istasyonlarının yer seçimini ele almak için bir coğrafi bilgi sistemi (CBS) tabanlı MCDA yaklaşımı uygulamışlardır.

Çok kriterli karar verme teknikleri, karar vericilerin karmaşık karar sorunlarını bilimsel ve analitik bir çerçevede çözmelerine yardımcı olmaya çalışmaktadırlar. AHP, ANP, PROMETHEE, DEMATEL, TOPSIS, MOORA ve COPRAS gibi birçok çok kriterli 
karar verme tekniği bulunmaktadır. Bu metotlardan AHP özellikle kriterlerin ağırlıklandırılması noktasında sıklıkla kullanılmaktadır. Saaty'nin 1980'de [19] ortaya koyduğu analitik hiyerarşi süreci (AHP) yöntemi, CBS ile birlikte uygulandığında, bir problemi organize etmek ve alternatifleri görsel olarak göstermek için değerli bir araç olarak kullanılmaktadır [20]. Bu çalışmada da Balıkesir Üniversitesi Çağış kampüsünde, en uygun bisiklet paylaşım istasyonlarının tespit edilmesi için AHP ve CBS yöntemleri birlikte kullanılmıştır.

\section{Yöntem}

Bisiklet paylaşım istasyonu yer seçiminde iki problem vardır. İlki, bisiklet talebine yansıyan çevredeki insan faaliyetlerinin mekansal bilgileri ile ilgilidir. Bunun için, çevrenin ve istasyon ağ yapısının önerileceği ortamın coğrafi bilgileri gereklidir ve çalışmada CBS yöntemlerinden yararlanılmıştır. İkincisi, çevre niteliklerinin bisiklet paylaşım sistemleri arasındaki önemi veya etkisi eşit derecede değildir [7]. Çalışma kapsamında ilk olarak kampüs içinde bisiklet kullanımını etkileyecek kriterler belirlenmiş, bu kriterler ile ilgili gerekli veriler toplanmıştır. Belirlenen kriterlerin ağırlıklandırılması çok kriterli bir karar verme yöntemi olan AHP ile gerçekleştirilerek, istasyonların yerleştirilmesindeki etkileri farklılaştırılmıştır. Sonrasında ise yine CBS yardımıyla bu kriterler ayrı ayrı görsel hale getirilerek haritaları oluşturulmuş ve bu haritalar birleştirilerek bisiklet paylaşım istasyonları için bir uygunluk haritası elde edilmiştir. Bu harita üzerinde en uygun yerlere alternatif istasyon noktaları yerleştirilmiş ve bu noktaların objektif bir değerlendirmesini yapabilmek için yine AHP yöntemi kullanılmıştır.

AHP, Saaty tarafından 1970'lerde, karmaşık karar problemlerinde öncelikleri belirlemek amacıyla geliştirilmiş pratik çok kriterli bir karar verme tekniğidir. Dokuzlu karşılaştırma cetvelini kullanan AHP, soyut verileri de dikkate alan, kriter, alt kriter ve alternatifler hiyerarşisi olarak tanımlanmaktadır [21].

CBS, sadece olayları, etkinlikleri veya nesneleri tespit etmek değil, aynı zamanda konum kavramını da kullanarak bu olayların, etkinliklerin veya nesnelerin nerede gerçekleştiğini de dikkate alan özel bir "bilgi sistemleri" sınıfidır. Bilgi sistemleri genel olarak, bilgiyi organize edip saklayarak, bilgileri sentezlemeye ve yönetmeye yardım eden sistemlerdir [22]. Verilerin ham hali sadece doğrudan görülebilen bilgileri verirken, bu verilerin bilgi sistemleri ile işlenmesi yeni çıkarımlar yapma imkanı sunar. Coğrafi bilgi sistemleri (CBS) ise bunu dünyanın yüzeyini ele alan konum verisi ile gerçekleştirmektedir. Dolayısı ile, CBS ile dünya yüzeyindeki konumlarla ilgili verileri elde etmek, depolamak, analiz etmek ve görüntülemek mümkün hale gelmektedir. Bu sayede gerçek dünyada kullanılabilecek işlenmiş veriler elde edilebilmektedir (Şekil 2).

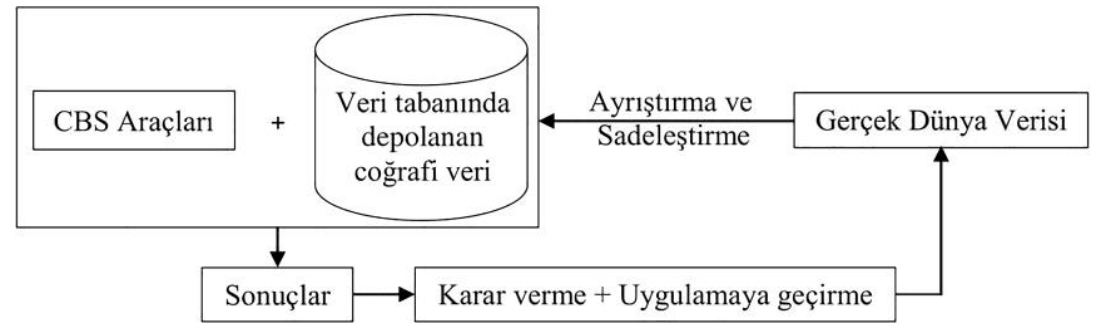

Şekil 2. CBS ile verilerin işlenme süreci [23]. 
CBS üzerinde, raster veya vektör olarak girilen her veri türü için ayrı bir katman oluşturulmaktadır. Katmanlar, tanımladıkları nesnelere göre şekil ve bilgi bakımından farklılık gösterebilmektedirler [7]. Kullanılan metodolojinin aşamaları Şekil 3'te sunulmuştur. Bu aşamalar ilerleyen bölümlerde daha detaylı olarak anlatılacaktır.

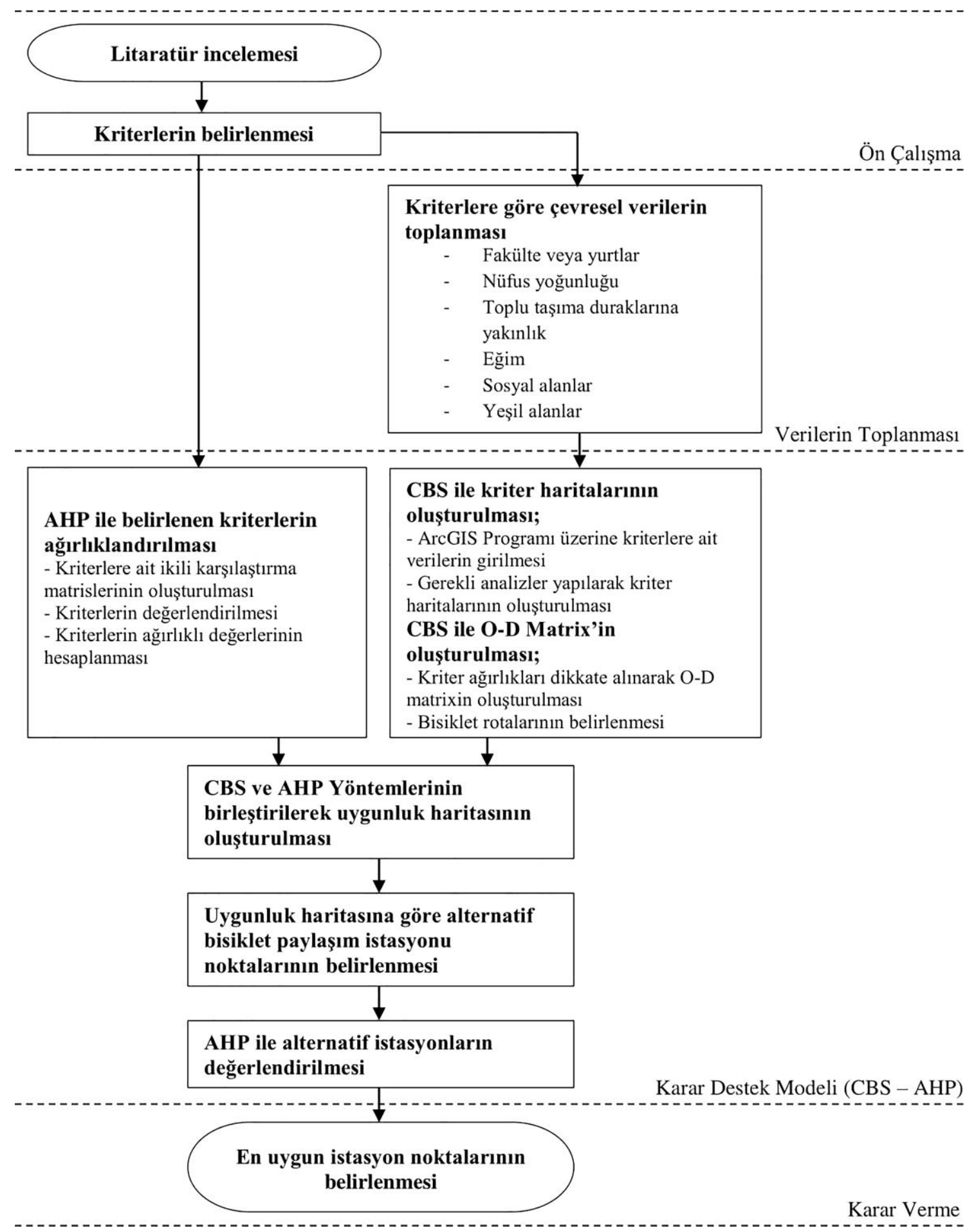

Şekil 3. Kullanılan metodolojinin aşamaları.

Balıkesir Üniversitesinde toplam 11 fakülte lisans yüksek lisans ve doktora düzeyinde eğitim vermektedir. Bu fakültelerden Necatibey Eğitim Fakültesi kampüs içerisinde değil, kent merkezinde olduğu için çalışma kapsamı dişında tutulmuştur. Çağış 
kampüsü içerisinde bulunan fakültelerde birinci ve ikinci öğretim olmak üzere lisans düzeyinde toplam 15.985 öğrenci öğrenim görmektedir. Çağış Kampüsü içerisindeki fakülteler genellikle birbirinden bağımsız, doğrusal bir hat üzerine yerleşmiş durumdadırlar. Kampüs içerisinde Kredi ve Yurtlar Kurumu'na (KYK) bağlı yurtlar ve bir özel yurt bulunmaktadır. Bu yurtlarda kalan öğrenciler, kent merkezine ulaşımın zorluğundan dolayı günlük ihtiyaçlarını çoğunlukla kampüs içerisinden karşılamaktadırlar. Özellikle bu yurtlarda kalan öğrencilerin sunulacak olan bisiklet yolları ve bisiklet paylaşım istasyonlarının ana kullanıcıları olacağı varsayılmaktadır.

İlk olarak ilgili literatür incelenerek, Çağış Kampüsünde bisiklet rotaları ve paylaşım istasyonlarının belirlenmesinde etkili olan değerlendirme kriterleri (Tablo 1) belirlenmiştir [7, 24]. Kriterler belirlenirken Çağış kampüsünün öznitelikleri ve bisiklet kullanımının gerektirdiği nitelikler birlikte ele alınmıştır. Değerlendirme kriterleri; kullanıcılar, ulaşım ağı ve kampüs içi yaşam olmak üzere bisiklet hareketliliğinin farklı yönlerine odaklanmaktadır. Çalışma kapsamında belirlenen kriterler Tablo 1'de ifade edilmiştir:

Tablo 1. Kampüste bisiklet kullanımı ile ilgili belirlenen kriterler.

\begin{tabular}{|c|c|}
\hline Kriterler & Açıklaması \\
\hline \multicolumn{2}{|l|}{ A. Kullanıcı Odakı Nitelikler } \\
\hline A.1. Fakülte ve yurtlara yakınlık & $\begin{array}{l}\text { Kampüsteki fakülte ve yurtlar bisiklet paylaşım sisteminin ana } \\
\text { kullanıcılarını oluşturacaktır. }\end{array}$ \\
\hline A.2. Nüfus yoğunluğu & $\begin{array}{l}\text { İnsan yoğunluğunun fazla olduğu alanlar için daha fazla } \\
\text { istasyon gerekecektir. } 1000 \text { kişiye en az bir tane istasyon } \\
\text { gerekmektedir [24]. }\end{array}$ \\
\hline \multicolumn{2}{|l|}{ B. Ulaşım Ăğı Nitelikleri } \\
\hline B.1. Toplu taşıma duraklarına yakınlık & $\begin{array}{l}\text { Bisikletin de bir toplu taşıma aracı olarak kullanılması adına } \\
\text { toplu taşıma durakları ile bütünleşmesi önemli görülmektedir. }\end{array}$ \\
\hline B.2. Eğim & $\begin{array}{l}\text { Bisiklet kullanımı için \%4'e kadar olan eğimler problem } \\
\text { olussturmazken; \%4 - \%8 arası bisiklet kullanımın } \\
\text { zorlaştırmakta; } \% 8 \text { üstü eğimler ise bisiklet kullanımına imkan } \\
\text { vermemektedir [24]. }\end{array}$ \\
\hline \multicolumn{2}{|l|}{ C. Kampüs İçi Yaşam İle İlgili Nitelikler } \\
\hline C.1. Sosyal ve hizmet alanlarına yakınlık & $\begin{array}{l}\text { Öğrencilerin ve personelin sosyal ve hizmet alanlarına } \\
\text { ulaşımında kullanabilmeleri sağlanmalıdır. }\end{array}$ \\
\hline C.2. Yeşil alanlara yakınlık & $\begin{array}{l}\text { Bisiklet sürerken hem keyif alma hem de gölge sağlamas } \\
\text { açısından yeșil alanlara yakın olması önemli görülmektedir. }\end{array}$ \\
\hline
\end{tabular}

Kriterlerin belirlenmesinin ardından, en uygun bisiklet paylaşım istasyonu yeri seçiminde bu kriterlerin ağırlıkları aynı olmayacağı için, AHP yöntemiyle kriter ağırlıkları belirlenmiştir.

AHP tekniği tarafından belirlenen kriter ağırlıkları, CBS yardımıyla bisiklet paylaşım istasyonu yerlerinin uygunluk haritasını oluşturmak için kullanılmıştır. Bu çalışmada ArcGIS Pro programı, bisiklet paylaşım istasyonu yeri seçim probleminin çevresel verilerini dikkate almak için kullanılmıştır. ArcGIS Pro programında ilk olarak kullanıcıların akışına göre başlangıç ve varış noktaları belirlenerek O-D matrisi oluşturulmuştur. Çalışmada, öğrenci, öğretim üyesi ve personelin kendi bulundukları binalar ve yurt binaları "başlangıç noktaları (origin)", üniversite kullanıcılarına hizmet veren alanlar ise "varış noktaları (destination)" olarak kabul edilmiştir. Bu matris ile elde edilen "desire line" diyagramı, yolculuk başlangıç noktasını ve seyahat arzusunun hedeflerini birbirine bağlayan düz çizgilerden oluşmaktadır ve buradaki hatların farklılıkları, göreceli seyahat arzusu miktarlarını göstermektedir [9]. Bu diyagram ile birlikte kullanım yoğunluğu olan hatlar tespit edilerek bisiklet rotaları belirlenmiştir. 
Toplanan kriter verileri de ArcGIS Pro programına girilerek kriter haritaları oluşturulmuş ve görsel hale getirilmiştir. Bu aşamadan sonra, AHP ile karar verilen kriter ağırlıklarına göre uygunluk haritası oluşturulmuş ve bu haritaya göre alternatif bisiklet paylaşım istasyonları belirlenmiştir. Belirlenen alternatif istasyon noktaları AHP ile değerlendirilerek, en uygun noktalar tespit edilmeye çalışılmıştır. $\mathrm{Bu}$ çalışmada kullanılan karar verme sürecindeki AHP hiyerarşisi Şekil 4'de verilmiştir.

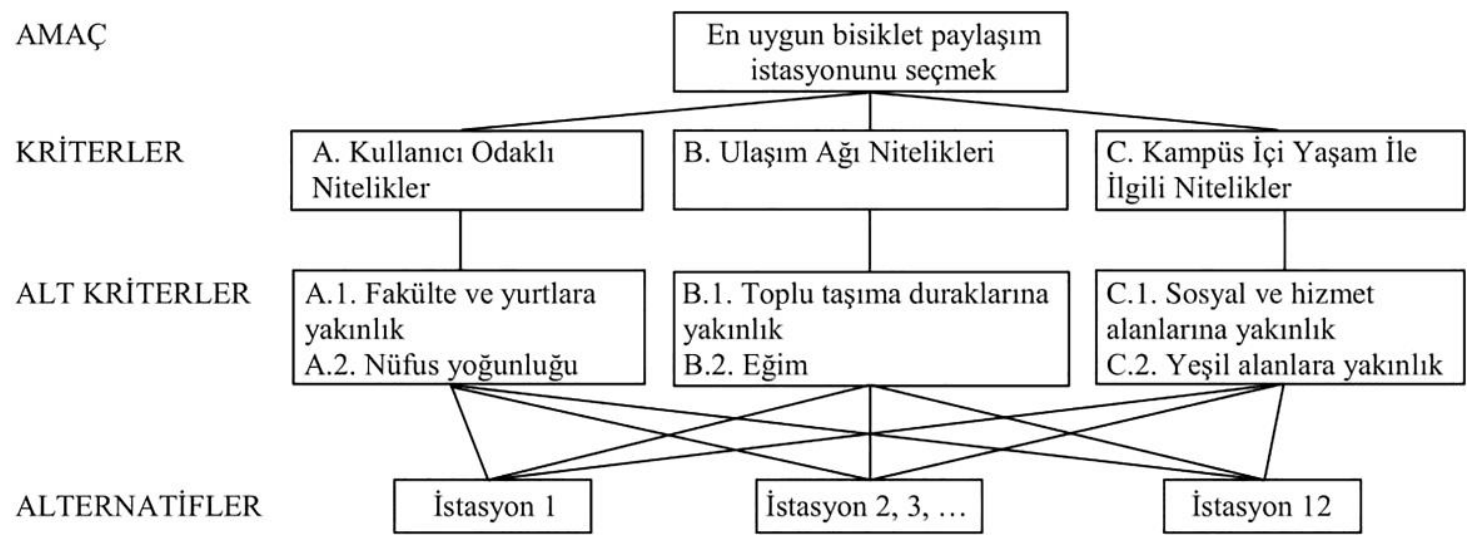

Şekil 4. Bisiklet istasyonlarının ağırlıklandırılmasında kullanılan kriterler hiyerarşisi.

AHP yöntemi CBS ile birlikte birçok alanda etkili bir karar verme yaklaşımı olarak kullanılmaktadır. Gerçekleştirilen çalışmada ise bir bisiklet paylaşım sistemi oluşturmak için bu yöntemlerin bir arada kullanılabileceği, kullanıcı ve çevre verilerinin de dahil olduğu karmaşık karar verme problemlerine verimli bir çözüm sunacağ öngörülmektedir. Bisiklet paylaşım istasyonlarının belirlenmesinde kullanılan karar destek modelinin çalışma prensibini gösteren akış şeması Şekil 5'te verilmiştir.

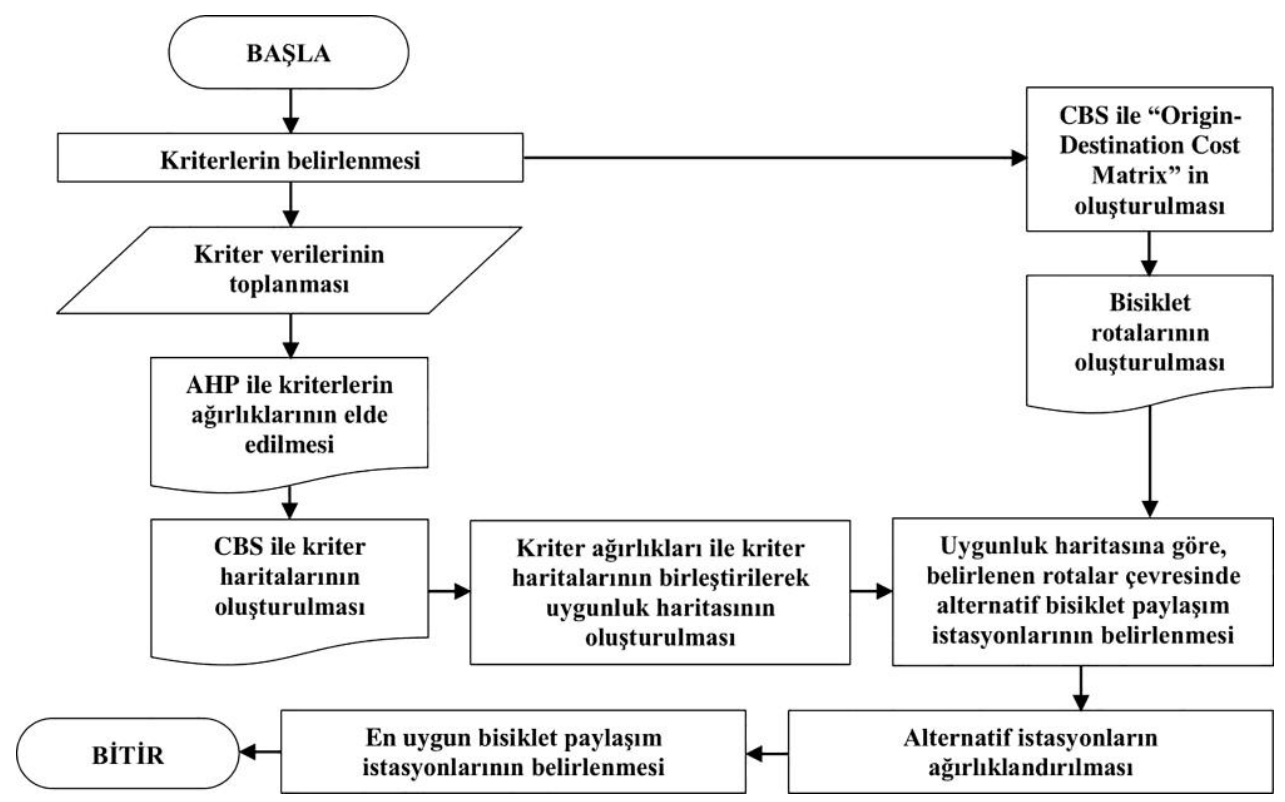

Şekil 5. Karar destek modelinin akış şeması.

Gerçekleştirilen çalışmanın uygulanması halinde, ekolojik açıdan gürültü ve hava kirliliğini azaltacağı ve fiziksel olarak daha aktif, sağlıklı ve keyifli bir kampüs yaşamı sunacağ1 düşünülmektedir. Yöntemin kent içi farklı alanlarda da uygulanması ile 
verimli bir şekilde kullanılan bisiklet paylaşım sistemleri oluşturularak, kentlilerin yaşam kalitesi üzerinde olumlu etki göstereceği düşünülmektedir.

\section{Yöntemin uygulanması}

$\mathrm{Bu}$ bölümde, sunulan yöntemin Balıkesir Üniversitesi Çağış Kampüsü özelinde uygulanışı ele alınacaktır. Öncelikle bisiklet rotalarının oluşturulması, sonrasında ise bisiklet paylaşım istasyonları için en uygun yerlerin belirlenmesi problemlerinin ele alınışı ve sonuçları, gerçekleştirilen CBS analizleri ve çok kriterli karar verme yöntemiyle yapılan değerlendirmeler aşamalandırılarak anlatılacaktır. Kampüs içinde güvenli bisiklet kullanımını mümkün kılmak için ilk olarak bisiklet rotalarının oluşturulması gerçekleştirilmiştir.

\subsection{Bisiklet rotalarının oluşturulması}

İlk olarak kampüsteki öğrenci ve personelin akışına göre kampüsün kullanımı ortaya çıkarılmaya çalışılmıştır. Kampüs içinde fakülte ve yurtlar "başlangıç noktası"; yemekhane, kafeteryalar, spor alanları, cami, hastane ve rektörlük binası gibi sosyal ve hizmet alanları ise "varış noktası" olarak belirlenerek, ArcGIS Pro programı üzerinde işaretlenmiştir. Çalışmanın, kampüsün önümüzdeki yıllardaki kullanımına uygun olması adına yeni yapılmakta olan Kütüphane ve Kültür Merkezi Binası, İlahiyat Fakültesi Binası gibi inşaat halinde olan yapılar bitmiş olarak kabul edilerek dikkate alınmıştır. Belirlenen başlangıç ve bitiş noktaları arasında "Origin-Destination Cost Matrix" kullanılarak mesafeye göre O-D Matrisi Şekil 6'daki gibi oluşturulmuştur.

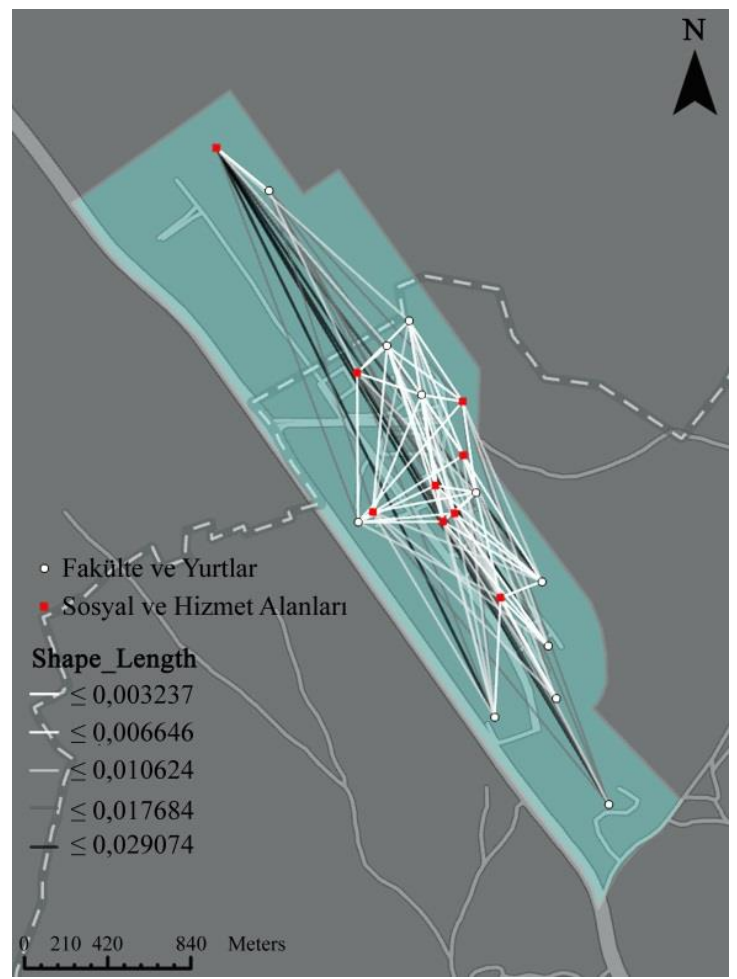

(a)

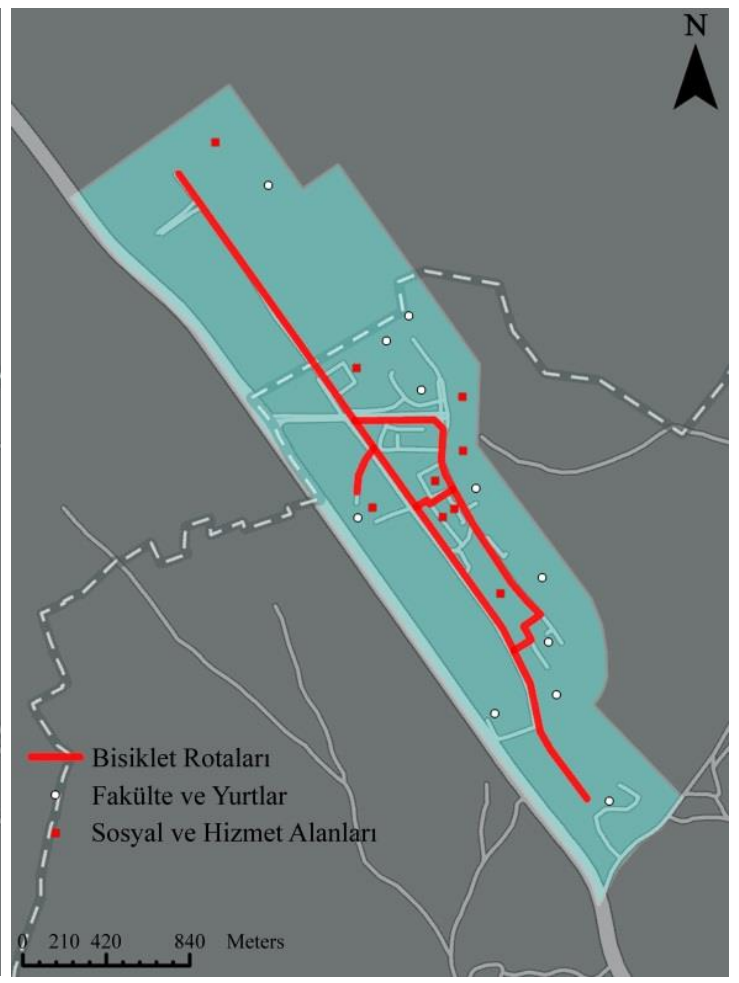

(b)

Şekil 6. (a) Mesafeye göre oluşturulan O-D Matrisi; (b) Oluşturulan bisiklet yolları. 
Şekil 6 (a)'da sunulan matristeki daha açık renkle belirtilen çizgiler 300 m.'ye kadar olan mesafeleri ifade etmektedir. $300 \mathrm{~m}$. den az olan yerlere yaya ulaşımı mümkün olduğu için daha çok koyu renkle ifade edilen çizgiler dikkate alınarak Şekil 6 (b)'deki kampüs içindeki bisiklet rotaları oluşturulmuştur.

Matris üzerindeki yoğunlaşan bölgelere rotaların ulaşımının sağlanmasına ve $300 \mathrm{~m}$. den fazla yürüyüş mesafesi oluşturulmamaya çalışılarak kampüsün bisiklet rotaları belirlenmiştir. Bu noktada, haritaya da bakıldığında siyah çizgilerle ifade edilen yurt ve hastane arasında bir ana yatay hat oluşturulmuş, sonrasında ise sosyal ve eğitim alanlarının yoğunlaştığı ikinci bir yatay hat oluşturulmuştur. Bu iki hat üzerinde eğim az olup, kampüs içindeki bisiklet kullanımının ana yolları olacağı düşünülmektedir. Belirlenen iki yatay hattı birleştirmek için ise eğimin daha az olduğu bağlantılar tercih edilmeye çalışılarak matrisin yoğunlaştığ 1 yerlerde dikey bağlantılar belirlenmiştir. Oluşturulan bisiklet yollarında eğim Balıkesir Üniversitesi Yapı İşleri Daire Başkanlığından temin edilmiş olan haritalar üzerinden incelenmiştir. Uygun bağlantı rotaları olarak görülen Mühendislik ve Mimarlık Fakültelerinin yanından geçen yolda eğimin en fazla \%6.21; yemekhanenin yanındaki yolda \%7.83; Turizm Fakültesinin yanındaki yolda ise \%8.07 olduğu tespit edilmiştir. Kampüs içerisinde belirlenen bütün rota içerisinde yalnızca Turizm Fakültesinin yanındaki yolda eğim \%8'i geçmektedir. Ancak bu yola alternatif yolların uzakta olması nedeniyle yaya olarak ulaşım zor olacağı için, bu yol da bisiklet rotası olarak kabul edilmiştir.

Khadem'in yaptığı gibi bazı çalışmalarda O-D matrisi, bazı hesaplamalarla birlikte bisiklet paylaşım istasyonlarının yerlerini belirlemekte de kullanılmıştır [25]. Ancak bu çalışmada yalnızca bisiklet rotalarını oluşturmak için gerekli hareket akışını belirlemekte kullanılmıştır. Kampüs içerisindeki hareket akışı çok karmaşık olmadığından tahmin edilebilir bir matris elde edildiği görülmektedir. Yöntem kent içi gibi daha karmaşık bölgelerde kullanıldığında, rotaların oluşturulmasına daha fazla katkı sağlayacaktır. Rotaların oluşturulmasının ardından, bisiklet paylaşım istasyonları alternatiflerinin belirlenmesi için uygunluk haritası oluşturulması aşamasına geçilmişsir. Bu uygunluk haritasını oluşturmak için öncelikli olarak kullanılacak olan kriterlerin ayrı ayrı haritalarının oluşturulması gerekmektedir.

\subsection{Kriter haritalarının oluşturulması}

Kriter haritalarının oluşturulması için ilk olarak belirlenen altı adet kritere ait elde edilen veriler ArcGIS Pro Programında haritalar üzerine işlenmiştir. Sonrasında bu işlenen verilere Tablo 2'deki analizler uygulanmıştır.

Tablo 2. Kriterlerin veri kaynakları ve uygulanan analiz yöntemleri.

\begin{tabular}{lllll}
\hline Kriter & Kriter Açıklaması & Veri & Veri Kaynă̆ı & Analiz Yöntemi \\
\hline A.1. & $\begin{array}{l}\text { Fakülte ve yurtlara } \\
\text { yakınlık }\end{array}$ & Fakülte ve yurtlar & Üniversite İmar Haritası & $\begin{array}{l}\text { Euclidian } \\
\text { Distance }\end{array}$ \\
\hline A.2. & Nüfus yoğunluğu & $\begin{array}{l}\text { Fakülte ve yurtların toplam } \\
\text { öğrenci ve personel sayıları }\end{array}$ & $\begin{array}{l}\text { Balıkesir Üniversitesi 2018- } \\
\text { 2019 Faaliyet Raporu }\end{array}$ & Kernel Density \\
\hline B.1. & $\begin{array}{l}\text { Toplu taşıma } \\
\text { duraklarına yakınlık }\end{array}$ & Toplu taşıma durakları & Baltus Mobil Uygulama & $\begin{array}{l}\text { Euclidian } \\
\text { Distance }\end{array}$ \\
\hline B.2. & Eğim & Eğim & $\begin{array}{l}\text { ALOS World 3D - 30m } \\
\text { (AW3D30) }\end{array}$ & Slope \\
\hline C.1. & $\begin{array}{l}\text { Sosyal ve hizmet } \\
\text { alanlarına yakınlık }\end{array}$ & Sosyal ve hizmet alanları & Üniversite İmar Haritası & $\begin{array}{l}\text { Euclidian } \\
\text { Distance }\end{array}$ \\
\hline C.2. & $\begin{array}{l}\text { Yeşil alanlara } \\
\text { yakınlık }\end{array}$ & Yeşil alanlar & Google Earth Pro & $\begin{array}{l}\text { Euclidian } \\
\text { Distance }\end{array}$ \\
\hline
\end{tabular}


$\mathrm{Bu}$ analizler sonucunda elde edilen kriter haritaları Şekil 7'de sunulmuştur. Böylece sayısal verilerin coğrafik olarak görselleştirilmesi ve daha anlaşılır hale gelmesi sağlanmıştır.
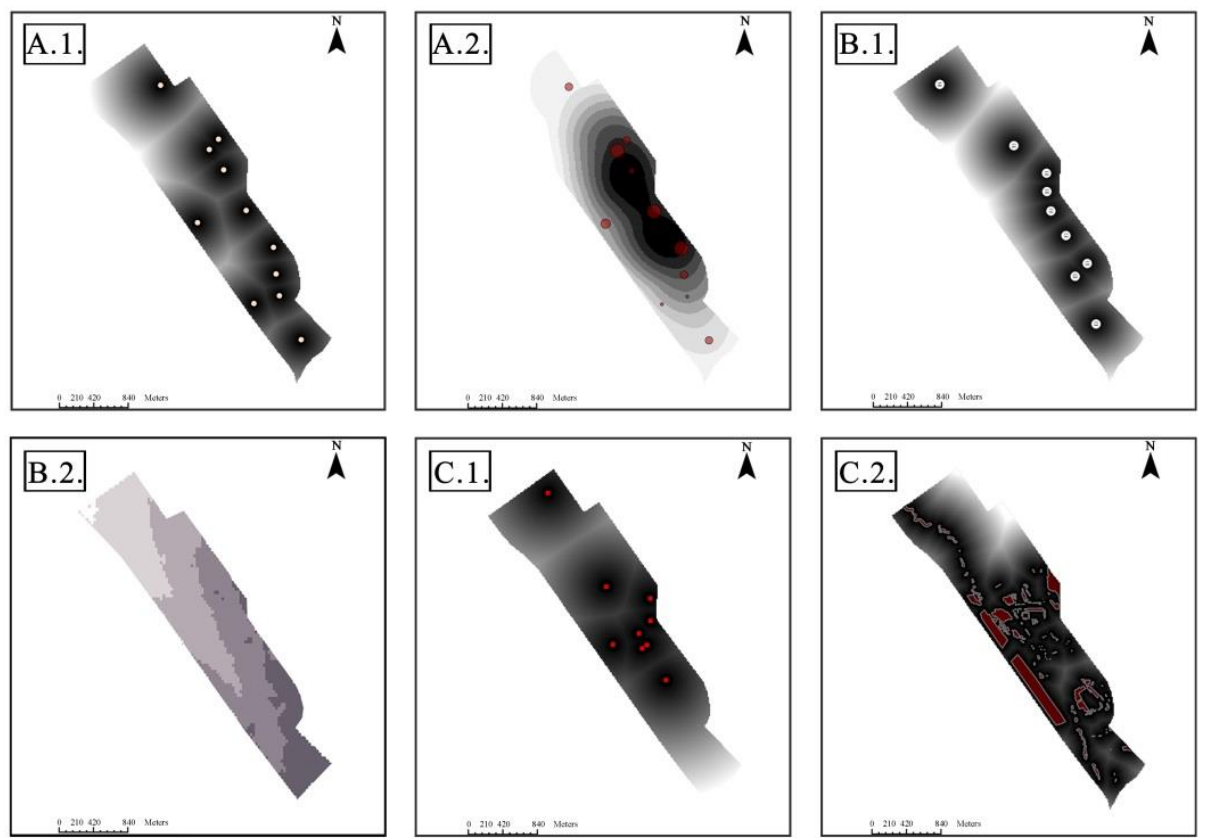

Şekil 7. Her bir kritere göre oluşturulan harita katmanları.

Şekildeki kriter haritaları incelenerek belirlenen kriterlere göre kampüs içerisinde nerelerde yoğunlaşmalar olduğu açıkça görülebilmektedir. Dolayısıyla bisiklet paylaşım istasyonlarının yerleştirilmesi bağlamında, kriter bazında uygun alanlar ortaya çıkmaktadır. Örneğin bisiklet paylaşım istasyonlarının sosyal ve hizmet alanlarına yakın olması isteniyorsa Şekil 7'deki C.1. haritasında koyu olarak gösterilen alanlara öncelik verilmelidir. Ancak kriterlerin tamamını en uygun şekilde ele alan istasyonları belirleyebilmek için, ayrı ayrı elde edilen bu haritaların, bir sonraki bölümde anlatıldığ üzere belirlenen kriter ağırlıklarına göre, ArcGIS Pro programında birleştirilerek uygunluk haritasının oluşturulması gerekmektedir.

\subsection{Kriterlerin ăğırlıklandırılması}

Bisiklet paylaşım modellerinde belirlenen kriterler aynı önem derecesine ya da sistemin kullanılmasında aynı etkiye sahip olmamaktadırlar [7]. Çalışmada, kriter ağırlıklandırmaları "SuperDecisions" [26] yazılımı kullanılarak gerçekleştirilmiştir. SuperDecisions, AHP (Analytic Hierarchical Process) ve ANP (Analytic Network Process) yöntemlerini uygulama imkanı sunan bir karar destek yazılımıdır. Bu çalışmada SuperDecisions yazılımı aracılığıyla çok kriterli bir karar verme tekniği olan AHP yöntemi kullanılmıştır. İlk olarak, belirlenen kriterler yazılım üzerinde tanıtılmış ve kriterler hiyerarşisi oluşturulmuştur. $\mathrm{Bu}$ aşamadan sonra belirlenen kriterlerin ağırlıklarının hesaplanması için, 1'den 9'a kadar çift yönlü olarak değer verilebilen ikili karşılaştırmaların gerçekleştirilmesi gerekmektedir. Örneğin A.1. (fakülte ve yurtlara yakınlık) ve A.2. (nüfus yoğunluğu) kriterleri bisiklet paylaşım istasyonlarının yerleştirilmesindeki önemi karşılaştırılarak, A.1. yönünde 2 değeri verilirse, A.1.'in A.2.'den daha önemli olduğunu, ancak önemlilik derecesinin çok güçlü olmadığını ifade etmektedir. Ancak seçilen değer 9 olursa, A.1.'in A.2.'ye göre çok daha fazla önemli 
olduğu sonucuna varılabilir. Yazılım üzerinden bütün kriterlere ait ikili karşılaştırmalar gerçekleştirilerek, ağırlıklandırılmış kriter değerleri Tablo 3'te verildiği gibi elde edilmiştir.

Tablo 3. Değerlendirme sonucunda belirlenen kriter ağırlıkları.

\begin{tabular}{lcc}
\hline \multicolumn{1}{c}{ Kriter } & A ğırlıklandırılmamış Değerler & A ğırlıklandırılmış Değerler \\
\hline A. Kullanıcı Odaklı Nitelikler & & \\
\hline A.1. Fakülte ve yurtlara yakınlık & 0.750000 & 0.505358 \\
\hline A.2. Nüfus yoğunluğu & 0.250000 & 0.168453 \\
\hline B. Ulaşım A Ă̆ı Nitelikleri & & \\
\hline B.1. Toplu taşıma duraklarına yakınlık & 0.125000 & 0.012582 \\
\hline B.2. Eğim & 0.875000 & 0.088072 \\
\hline C. Kampüs İçi Yaşam ile İlgili Nitelikler & & \\
\hline C.1. Sosyal ve hizmet alanlarına yakınlık & 0.888889 & 0.200476 \\
\hline C.2. Yeşil alanlara yakınlık & 0.111111 & 0.025060 \\
\hline
\end{tabular}

Kriterlerin ağırlıklandırılmasının ardından bu ağırlıkları doğrultusunda, yapılmış olan kriter haritalarının birleştirilerek bisiklet paylaşım istasyonları yerleri için uygunluk haritasının oluşturulması gerekmektedir.

\subsection{Uygunluk haritasının oluşturulması}

Kriterlerin ağırlıklandırılmış değerleri kullanılarak, ArcGIS Pro programında kriter haritaları birleştirilmiş ve Şekil 8'deki uygunluk haritası oluşturulmuştur. İlk olarak elde edilen Şekil 8 (a)'daki normalize edilmiş harita üzerine sınıflandırma işlemi uygulanarak, uygunluk derecesine göre sınıflara ayrılmış bölgeler elde edilmiştir (Şekil 8 (b)).

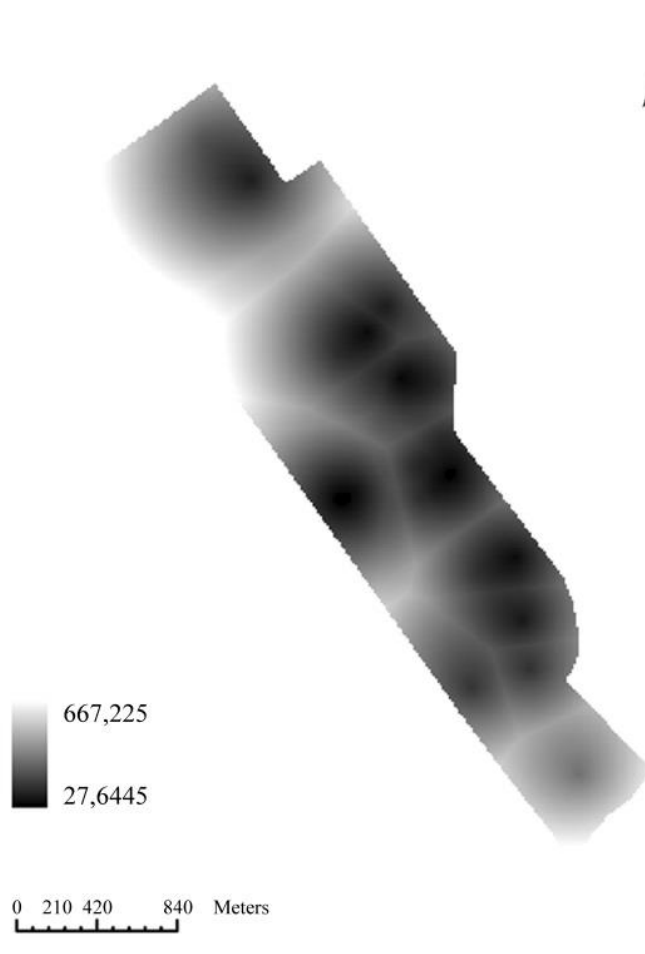

(a)

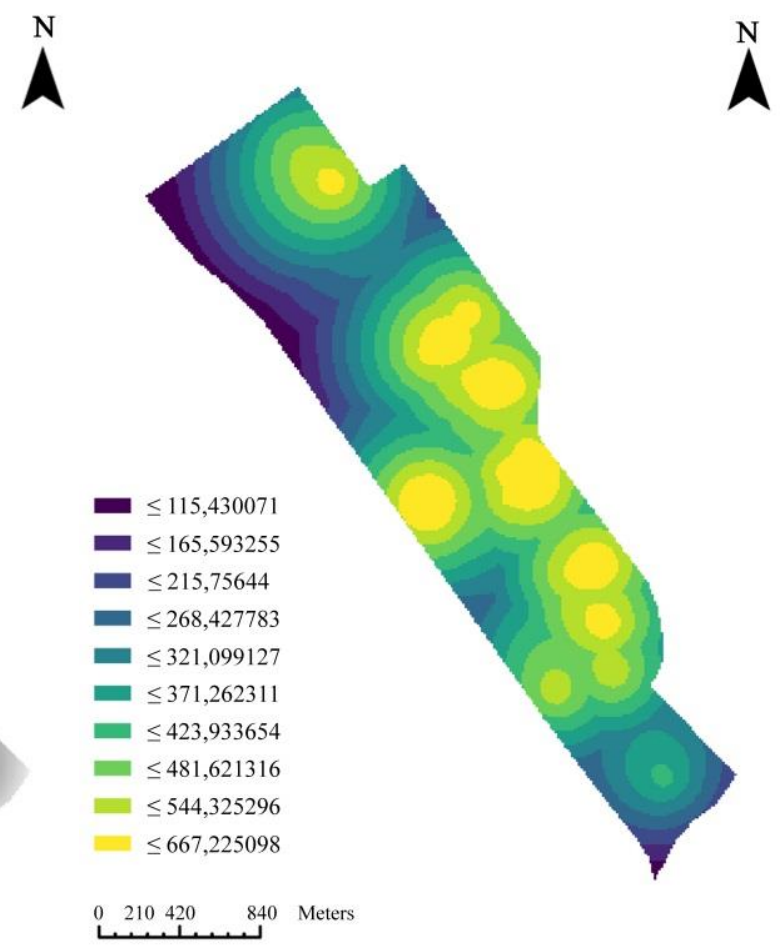

(b)

Şekil 8. (a) Normalize edilmiş uygunluk haritası; (b) Sınıflandırılmış uygunluk haritası. 
Ortaya çıkan haritada bisiklet paylaşım istasyonları için potansiyel alanlar maviden sarıya doğru daha uygun olacak şekilde görülmektedir. A.1. (fakülte ve yurtlara yakınlık) kriterinin katsayısı daha fazla olduğu için, fakülte ve yurtlara yakın alanların bisiklet paylaşım istasyonlarının yeri noktasında daha fazla potansiyel sahibi olduğu anlaşılmaktadır. Uygunluk haritası oluşturulduktan sonra, bu haritaya göre uygun olan noktalara alternatif istasyon noktalarının yerleştirilmesi gerekmektedir.

\subsection{Bisiklet paylaşım istasyonu alternatiflerinin belirlenmesi}

Uygunluk haritası ile ortaya çıkan bisiklet paylaşım istasyonu için en uygun ilk dört sınıf (Şekil 8 (b)) üzerinde bisiklet paylaşım istasyonu alternatifleri yerleştirilmiştir. Tüm fakülte, yurtlar, sosyal ve hizmet alanlarına ulaşımı sağlayacak şekilde toplam 12 adet bisiklet paylaşım istasyonu alternatifi Şekil 9 (a)'da görüldüğü gibi belirlenmiştir.

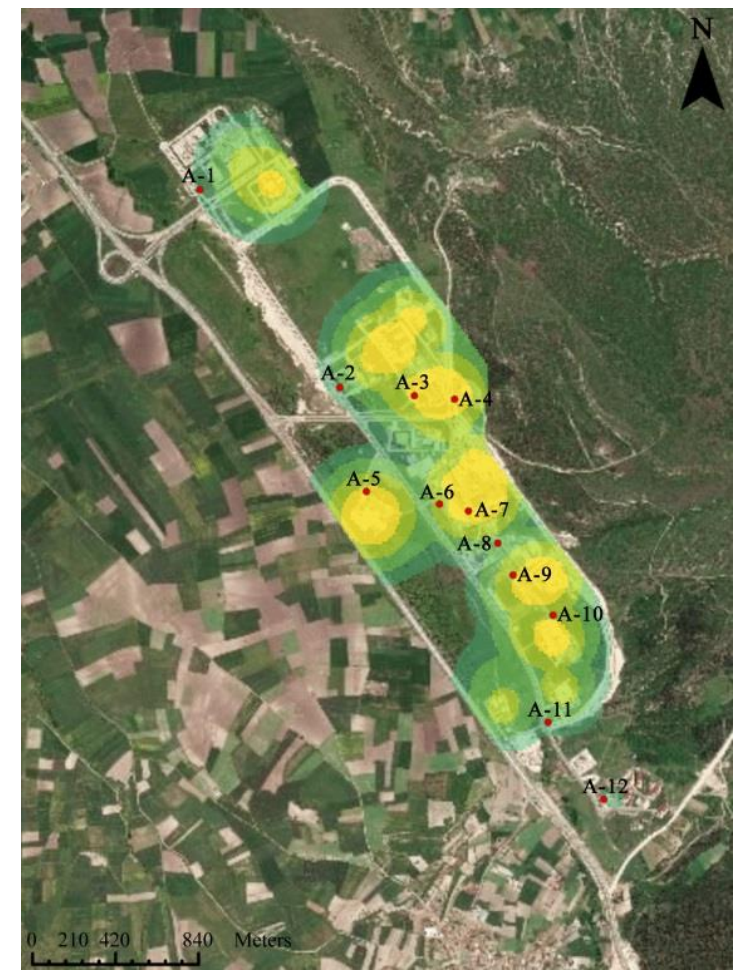

(a)

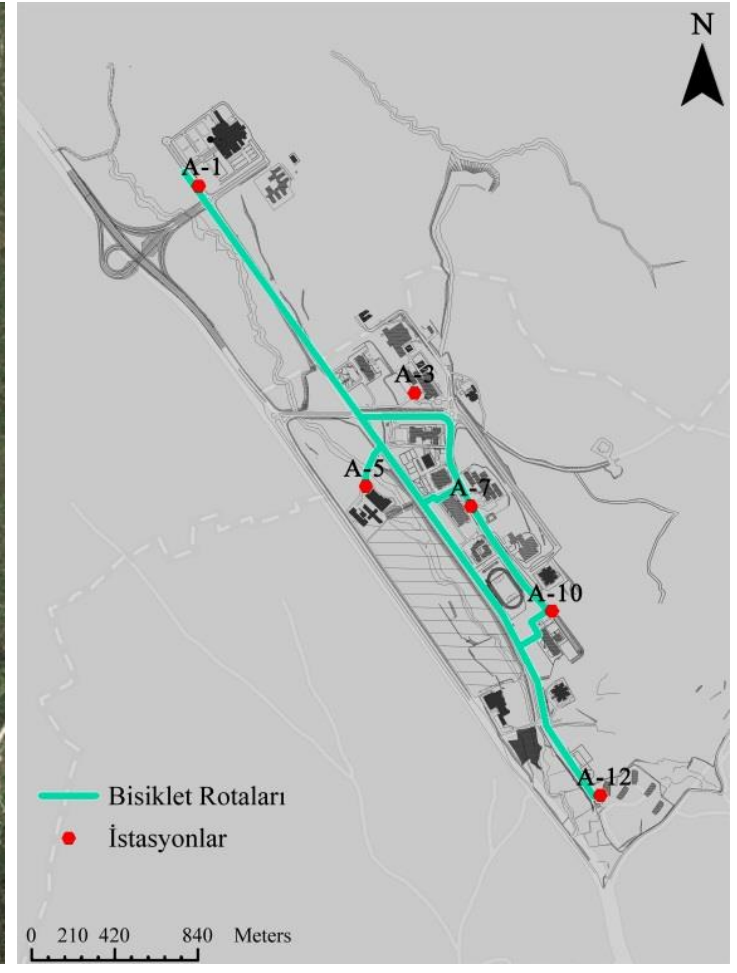

(b)

Şekil 9. (a) Uygunluk haritasına yerleştirilen alternatif bisiklet paylaşım istasyonları; (b) Değerlendirmeler sonucunda belirlenen bisiklet rotası ve paylaşım istasyonları.

Belirlenen istasyonlar arası $300 \mathrm{~m}$. mesafe olması normal olarak kabul edilmiştir. Literatüre bakıldığında, daha az mesafe istasyon fazlalığı oluşmasına sebep olurken, daha fazla mesafe ise, $300 \mathrm{~m}$.'den sonra yürüme isteğinin azalmasından dolayı, istasyonlara ulaşımı zorlaştıracağı için olumsuz olarak görülmektedir [24]. Buradan hareketle, olası bisiklet istasyonları alternatif yerleri için, başlangıç ve varış noktalarından en fazla 300 m'lik bir yürüyüş mesafesi seçilmiştir. Şekil 8 (b)'ye bakacak olursak, eğitim ve araştırma hastanesi ve tıp fakültesinin ve KYK yurtlarının bulundukları bölgeler, mesafeler dolayısıyla diğer kısımlardan biraz ayrılmış durumdadır. Alternatifler, hastane ve yurtlar bölgesine birer tane olacak şekilde, diğer alanlara ise uygun alanlar göz önünde bulundurularak dengeli bir şekilde dağıtılmaya çalışılmıştır. Alternatiflerin yerleştirilmesi çoğunlukla toplu taşıma durakları yanları ya da otopark alanları düşünülerek gerçekleştirilmiştir. Böylece istasyon noktalarının 
halihazırda ulaşımda kullanılmakta olan alanlara entegre edilmesiyle daha etkili kullanılması hedeflenmiştir.

\subsection{Alternatiflerin ağırlıklandırılması}

12 Adet bisiklet paylaşım istasyonu alternatifleri belirlendikten sonra, yine SuperDecisions yazılımı üzerinden çok kriterli karar verme yöntemi olan AHP ile ağırlıklandırılmaları gerçekleştirilmiştir. Öncelikle, alternatifler model hiyerarşisine eklenerek ilişkili olduğu kriterler programa tanıtılmıştır. Daha sonra ise, her bir kritere göre alternatif istasyonların ikili karşılaştırmaları gerçekleştirilmiştir. $\mathrm{Bu}$ değerlendirmeler ilgili kriter altında hangi alternatifin ne kadar daha uygun olduğu yine çift yönlü 9'lu karşılaştırma cetveline göre seçilerek gerçekleştirilmiştir. Alternatiflere ait tek tek kriter bazında ve toplam ortaya çıkan sonuç değerler Tablo 4'te ifade edilmiştir.

Tablo 4. Alternatiflerin kriterlere göre ve sonuç değerleri.

\begin{tabular}{|c|c|c|c|c|c|c|c|}
\hline & \multicolumn{6}{|c|}{ Kriterler } & \multirow[t]{2}{*}{ Sonuç Değerler } \\
\hline & $\begin{array}{c}\text { A.1. } \\
(0.505358)\end{array}$ & $\begin{array}{c}\text { A.2. } \\
(0.168453)\end{array}$ & $\begin{array}{c}\text { B.1. } \\
(0.012582)\end{array}$ & $\begin{array}{c}\text { B.2. } \\
(0.088072)\end{array}$ & $\begin{array}{c}\text { C.1. } \\
(0.200476)\end{array}$ & $\begin{array}{c}\text { C.2. } \\
(0.025060)\end{array}$ & \\
\hline A-1 & 0.034828 & 0.032900 & 0.123017 & 0.119920 & 0.039897 & 0.035529 & 0.307635 \\
\hline A-2 & 0.019531 & 0.020631 & 0.128494 & 0.119920 & 0.045448 & 0.058471 & 0.251596 \\
\hline A-3 & 0.125193 & 0.198168 & 0.049309 & 0.119920 & 0.071763 & 0.099453 & 0.869158 \\
\hline A-4 & 0.070838 & 0.078895 & 0.130792 & 0.067132 & 0.089607 & 0.146307 & 0.545548 \\
\hline A-5 & 0.151593 & 0.065931 & 0.018794 & 0.033732 & 0.105650 & 0.102044 & 0.799110 \\
\hline A-6 & 0.034256 & 0.027030 & 0.028120 & 0.023642 & 0.179539 & 0.063538 & 0.431310 \\
\hline A-7 & 0.103781 & 0.170487 & 0.082553 & 0.115186 & 0.248806 & 0.050104 & 1.000000 \\
\hline A-8 & 0.065656 & 0.065364 & 0.132495 & 0.062398 & 0.105256 & 0.031336 & 0.510438 \\
\hline A-9 & 0.035370 & 0.033761 & 0.044531 & 0.035440 & 0.063489 & 0.031336 & 0.284051 \\
\hline A-10 & 0.148786 & 0.161197 & 0.144457 & 0.057069 & 0.022452 & 0.289516 & 0.842909 \\
\hline A-11 & 0.058529 & 0.050964 & 0.034738 & 0.122820 & 0.014938 & 0.067172 & 0.377011 \\
\hline A-12 & 0.151639 & 0.094673 & 0.082701 & 0.122820 & 0.013155 & 0.025195 & 0.750647 \\
\hline
\end{tabular}

Tabloda da görüldüğü üzere, yemekhane önündeki A7 istasyonu en uygun alternatif olarak tespit edilmiştir. Kampüsün en sosyal, merkez olarak değerlendirilebilecek noktası burası olduğundan ağırlıklandırma sonuçlarının gerçek verilerle örtüştüğü söylenebilmektedir.

\subsection{Bulgular}

Çalışma kapsamında, öncelikli olarak bisiklet rotaları oluşturulmuş, sonrasında ise belirlenen kriter ağırlıklarına göre uygunluk haritası oluşturularak alternatif bisiklet paylaşım istasyon noktaları belirlenmiştir. Yine bu belirlenen kriterlere göre alternatiflerin değerlendirmeleri gerçekleştirilmiş ve değerlendirme sonuçları Tablo 4'te verilmiştir. Bu sonuçlara göre oluşan grafikler de Şekil 10'da sunulmuştur.

Tablo 4'ü incelediğimizde, kriter ağırlıklarının, alternatiflerin değerlerini de oldukça etkilediği görülmektedir. Örneğin; A-4 alternatifi "toplu taşıma duraklarına yakınlık (B.1.)" ve "yeşil alanlara yakınlık (C.2.)" kriterlerine göre yüksek değerler almış olsa da o kriterlerin ağırlıkları daha düşük olduğu için sonuç değeri 0.5 'lerde kalmıştır. Ya da A-12 alternatifi birçok kritere göre düşük değer almış olsa da ağırlığı fazla olan "fakülte ve yurtlara yakınlık (A.1.)" kriterinden yüksek değer aldığg için, sonuç değeri 0.7'nin üstüne çıkabilmiştir. Bu noktada, 0.505358 ile en yüksek ağırlığg olan A.1. (fakülte ve yurtlara yakınlık) kriterinin, sonuç değerlerde daha etkili olduğu gözlemlenmektedir. 
Şekil 10'da görüldüğü üzere değerlendirme sonucunda, potansiyel istasyon noktalarından sonuç değeri 0.7'nin üstünde olanlar uygulanacak olan istasyonlar olarak ele alınmıştır. Bu noktalar; A-3, A-5, A-7, A-10, A-12 istasyonlarıdır. Şekil 10 (a)'ya bakacak olursak, seçilen bu istasyonlardan; A-3, A.2. (nüfus yoğunluğu) kriterinde; A5, A.1. (fakülte ve yurtlara yakınlık) kriterinde; A-7, C.1. (sosyal ve hizmet alanlarına yakınlık) kriterinde; A-10, C.2. (yeşil alanlara yakınlık) kriterinde; A-12 alternatifi ise, C.1. (sosyal ve hizmet alanlarına yakınlık) kriterinde iyi olarak değerlendirilmiştir.

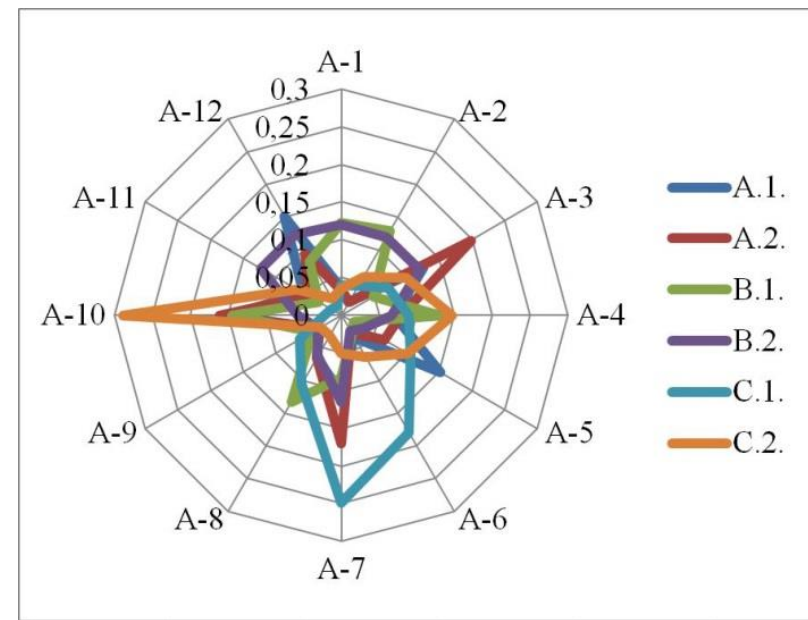

(a)

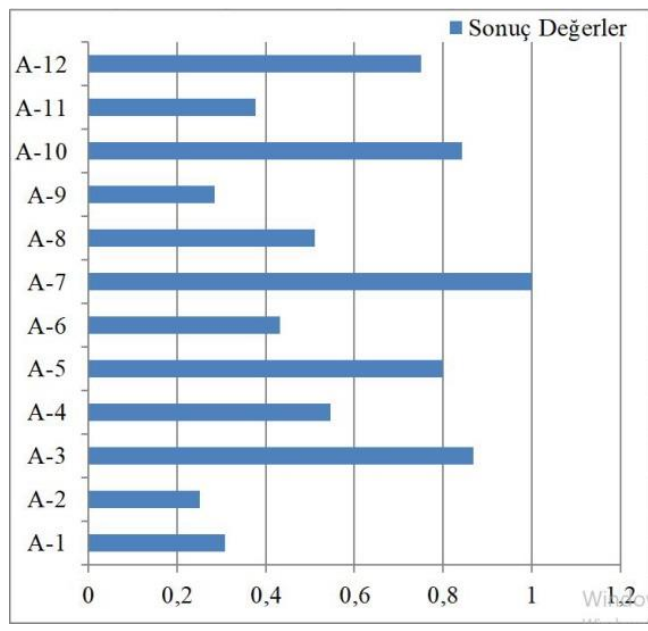

(b)

Şekil 10. (a) Alternatiflerin kriterlere göre ağırlıkları; (b) Alternatiflerin toplam ağırlıkları.

Değerlendirme sonucunda elde edilen beş potansiyel istasyon noktası incelendiğinde, Şekil 9 (b)'de de ifade edildiği şekilde kampüs içerisinde dengeli bir dağılım olduğu söylenebilir. Sadece, A-1 alternatifinin olduğu tıp fakültesi ve eğitim ve araştırma hastanesi bölgesinde bir istasyon yerleşememiş olarak görülmektedir. Bu noktada, kampüs içerisinde bisiklet kullanımının bütünlüğünün sağlanması ve 1000 kişi için en az bir tane istasyon bulunması gerekliliği koşulunu sağlaması adına A-1 alternatifi de önerilen istasyon noktalarına eklenmiş ve sonuçta elde edilen rota ve istasyon noktalarını gösteren harita Şekil 9 (b)'de sunulmuştur.

Bisiklet kullanımı motorlu taşıtlara göre belirli koşullara daha fazla bağımlıdır ve özellikle uygulaması yapılan bisiklet paylaşım istasyonlarının konumu, sistemin verimli kullanılabilmesi adına önemlidir. Bu nedenle çalışmada yapılan bisiklet kullanımı için uygun kriterlere göre bu istasyonların yerleşiminin yapılması sistemin kullanımının sağlanması açısından büyük önem taşımaktadır. Çalışma kapsamında elde edilen bisiklet paylaşım istasyonları incelendiğinde kampüs içerisinde genel olarak kampüsün önemli noktalarında oldukları görülmektedir. Bu anlamda kullanılan yöntemin bisiklet rotaları ve bisiklet paylaşım istasyonlarının belirlenmesi noktasında verimli olduğu söylenebilmektedir. Genç nüfus yoğunluğu fazla olan kampüste böyle elverişli bir sistemin kurulması sayesinde kampüsün araç hakimiyetinden kurtulmasının mümkün olabileceği düşünülmektedir. Çalışmada kampüs içerisinde çok karmaşık bir yap1 olmadığından sonuçlar tahmin edilebilir ölçektedir ancak, daha karmaşık yapıda olan kent içi alanlarda bu yöntem kullanıldığında, oluşabilecek karmaşık kriter ağlarına rasyonel sonuçlar ortaya çıkarabilmesi anlamında daha da verimli olabilecektir. Böylece bisiklet paylaşım istasyonlarının daha etkili kullanılması sağlanarak, bisiklet kullanımı 
yaygınlaştırılacak, daha sağlıklı ve ekolojik açıdan daha yaşanabilir bir ortam sağlanabilecektir.

\section{Sonuçlar ve tartışma}

Bisiklet paylaşım sistemlerinin sağlık, ekonomi ve çevre için sağladığı avantajlar dolayısıyla, özellikle daha enerjik bir yapıda olan üniversite kampüslerinde, çok fazla uygulanmaya başlanmıştır. Bu çalışmada, Balıkesir Üniversitesi, Çağış Kampüsünde araç hakimiyetini azaltacak bir bisiklet paylaşım sistemi kurulması için gerekli bisiklet rotaları ve uygun bulunan bisiklet paylaşım istasyon noktaları tespit edilerek sunulmuştur.

Bisiklet paylaşım sistemleri çevre dostu sistemler olarak görülmektedir, ancak sürekli kullanımını sağlamak için kullanıcı memnuniyeti önem arz etmektedir. Bu memnuniyet noktasında, bisiklet güzergahı ve kullanıcıların bulundukları ve gidecekleri yerlerde paylaşım istasyonlarının bulunması önemli hale gelmektedir. Aktif bir ulaşım aracı olarak bisikletin yer bulabilmesi için, bisiklet altyapısına ayrılan sınırlı kaynakların verimli bir şekilde kullanılabilmesi noktasında daha fazla potansiyelli olan alanları objektif olarak ortaya çıkaran yöntemler gerekmektedir [27]. Bu çalışmada en fazla potansiyeli olan alanları tespit etmek için CBS, yer tercihlerini objektif olarak gerçekleştirebilmek için de çok kriterli karar verme yöntemlerinden faydalanılmıştır. Bu iki yöntemin birleşimi birçok çalışmada farklı şekillerde denenmiş ve bisiklet paylaşım istasyonlarının yer seçimi konusunda verimli bulunmuştur [7, 12, 13, 18]. Bu kapsamda, öncelikle Çağış Kampüsünde öğrenci ve personel kullanımını gösteren O-D matrisi oluşturularak bisiklet rotaları belirlenmiştir. Daha sonra ise bisiklet kullanımı için üç ana kriter ve toplam altı alt kriterden oluşan kriterler hiyerarşisi belirlenmiş ve bu kriterlerin ağırlıkları SuperDecisions yazılımı ile elde edilmiştir. CBS yardımı ile kriter haritaları oluşturulduktan sonra belirlenen kriter ağırlıklarına göre uygunluk haritası oluşturulmuştur. $\mathrm{Bu}$ harita üzerinde en uygun yerlere alternatif bisiklet paylaşım istasyonları yerleştirilmiştir. Son olarak bu alternatifler SuperDecisions yazılımında AHP yöntemi ile değerlendirilerek en uygun 5 bisiklet paylaşım istasyonu tespit edilmiştir. Kampüsün hastane ve Tıp Fakültesi bölgesinde hiç istasyon olmaması dolayısıyla, bisiklet kullanımında kampüs bütünlügünü korumak ve sistemi daha etkili bir hale getirmek adına, bahsi geçen bölge üzerinde bir istasyon daha bu değerlendirme sonucuna eklenmiş ve toplam 6 istasyon noktası elde edilmiştir. Kullanılan yöntemin bisiklet paylaşım sistemini oluşturmada verimli olduğu ve uygulanması halinde kampüsün çevresel ve fiziksel yaşamına olumlu etki edeceği düşünülmektedir.

Benzer bir çalışma gerçekleştiren Kabak v.d. [7] de CBS ve çok kriterli karar verme yaklaşımlarını bir arada kullanarak, hem mevcut bisiklet paylaşım istasyonları için bir değerlendirme hem de ek bisiklet paylaşım istasyonları için alternatif yerler önermektedirler. Çalışma sonucunda önerilen lokasyonların, mevcuttaki istasyonlara göre daha fazla potansiyel sahibi oldukları tespit edilmiştir. Kampüste gerçekleştirilen bu çalışmada da yöntemin mevcut bisiklet paylaşım istasyonlarının analizini yapmanın yanında, yeni bir bisiklet paylaşım sistemi önerisini mümkün kıldığı görülmektedir. Kullanılan yöntem ile, belirlenen kriterler çerçevesinde, bisiklet paylaşım istasyonlarının en verimli olabilecek noktalara yerleştirilmesi mümkün olmaktadır. Böylece kampüs içerisinde mevcut olan kısa mesafeli yolculuklarda sürdürülebilir ulaşım yöntemlerinden olan bisikletin kullanımı yaygınlaştırılarak, daha temiz ve araç 
trafiği ve sorunlarından uzaklaştırılmış bir kampüse dönüşmesi ve dolayısıyla kampüs kullanıcılarının yaşam kalitesinin artmasına katkı sağlaması öngörülmektedir. Bu rota ve istasyonlarla entegre bir bisiklet paylaşım sistemi uygulaması geliştirilerek kampüs içinde daha etkin bir bisiklet kullanımı sağlanması ise sonraki çalışmalarda gerçekleştirilebilecektir. Bunun yanında, kriterlerde gerekli güncellemeler yapılarak, yöntemin farklı alanlarda veya farklı araçların (elektrikli bisiklet, scooter vb.) istasyonlarıyla ilgili uygulamalarda kullanılması mümkün olabilecektir.

\section{Kaynaklar}

[1] Benevolo, C., Dameri, R., P. ve D'Auria, B., Smart mobility in smart city, In: Empowering Organizations, Springer, (2016).

[2] Lee, J. H., Phaal, R. ve Lee, S. H., An integrated service-device-technology roadmap for smart city development, Technological Forecasting and Social Change, 80, 2, 286-306, (2013).

[3] Bamwesigye, D. ve Hlavackova, P., Analysis of sustainable transport for smart cities, Sustainability, 11, 7, (2019).

[4] Cerutti, P. S., Martins, R. D., Macke, J. ve Sarate, J. A. R., "Green, but not as green as that": An analysis of a Brazilian bike-sharing system, Journal of Cleaner Production, 217, 185-193, (2019).

[5] Makarova, I., Shubenkova, K., Vadim Mavrin, V., Boyko, A. ve Katunin, A., Development of sustainable transport in smart cities, Proceedings: IEEE 3rd International Forum on Research and Technologies for Society and Industry (RTSI), 1-6, Modena, (2017)

[6] Lin, J. R. ve Yang, T. H., Strategic design of public bicycle sharing systems with service level constraints, Transportation Research Part E, 47, 284-294, (2011).

[7] Kabak, M., Erbas, M., Çetinkaya, C. ve Özceylan, E., A GIS-based MCDM approach for the evaluation of bike-share stations, Journal of Cleaner Production, 201, 49-60, (2018).

[8] DeMaio, P., Bike-sharing: history, impacts, models of provision, and future, Journal of Public Transportation, 12, 4, (2009).

[9] Chan, W. T. ve Suja, T., A multi-criteria approach in designing bicycle tracks, In: Map Asia Conference, (2003).

[10] https://www.google.com/maps, (01.06.2020).

[11] Erbolat Taşabat, S., Cinemre, N. ve Şen, S., Financial performance evaluation of Turkish deposit banks by application of different weighting techniques in multicriteria decision making methods, Social Sciences Research Journal, 4, 2, 96110, (2015).

[12] Çol Yılmaz, D. ve Gerçek, H., Prioritization of integrated bicycle network clusters in Istanbul using analytic hierarchy process, Pamukkale Üniversitesi Mühendislik Bilimleri Dergisi, 20, 6, 215-224, (2014).

[13] Mosallanejad, M., Azadedel, Y. ve Dalirpour, S., Improving bicycle path in urban area using AHP and GIS, International Journal of Fundamental Arts and Architecture, 1, 1, 1-7, (2015).

[14] Pal, A. ve Zhang, Y., Free-floating bike sharing: Solving real-life large-scale static rebalancing problems, Transportation Research Part C, 80, 92-116, (2017). 
[15] Choudhary, K. D., Altaf Taher Shah, A. T. ve Kasture A. B., A suggestive implementation on study of an 1ot-based dock-less bicycle sharing venture, International Journal of Innovative Research in Engineering \& Multidisciplinary Physical Sciences, 6, 5, (2018).

[16] Namiot, D. ve Sneps-Sneppe, M., On bikes in smart cities, Automatic Control and Computer Sciences, 53, 1, 63-71, (2019).

[17] García-Palomares, J. C., Gutiérrez, J. ve Latorre, M., Optimizing the location of stations in bike-sharing programs: A GIS approach, Applied Geography, 35, 235-246, (2012).

[18] Erbaş, M., Kabak, M., Özceylan, E. ve Çetinkaya, C., Optimal siting of electric vehicle charging stations: a GIS-based fuzzy multi-criteria decision analysis, Energy, 163, 1017-1031, (2018).

[19] Saaty, T. L., The Analytic Hierarchy Process, New York: McGraw Hill, (1980).

[20] Saplığlu, M. ve Aydın, M. M., Choosing safe and suitable bicycle routes to integrate cycling and public transport systems, Journal of Transport \& Health, 10, 236-252, (2018).

[21] Saaty, T. L., The analytic hierarchy and analytic network processes: applications to decisions under risk, European Journal of Pure and Applied Mathematics, 1, 1, 122-196, (2008).

[22] Longley, P. A., Goodchild, M. F., Maguire, D. J., ve Rhind, D. W., Geographic Information Systems and Science, $2^{\text {nd }}$ edition, John Wiley \& Sons, New York NY, (2005).

[23] Bernhardsen, T., Geographic information systems: an introduction, $3^{\text {rd }}$ edition, John Wiley \& Sons, New York NY, (2002).

[24] Jahanshahi, D., Minaei, M., Kharazmi, O. A. ve Minaei, F., Evaluation and relocating bicycle sharing stations in mashhad city using multi-criteria analysis, International Journal of Transportation Engineering, 6, 3, 23, (2019).

[25] Khadem, N. K., Kabir, M. M., Banerjee, S., ve Jeihani, M., Bike station suitability on university campus using origin - destination matrix - a Morgan State University case study. Urban Science, 3, 74, (2019).

[26] http://www.superdecisions.com, (01.06.2020).

[27] Larsen, J., Patterson, Z., ve El-Geneidy, A., Build it. But where? The use of geographic information systems in identifying locations for new cycling infrastructure, International Journal of Sustainable Transportation, 7, 299317, (2013). 